\title{
CHARACTERISATION OF AQUILARIA HIRTA BASED ON MORPHOLOGY EVALUATION AND VOLATILE CHEMICAL COMPOUND
}

\author{
Mohd-Syafik MH ${ }^{1, *}$, Che-Mohd-Aizal CM${ }^{1}$, Siti-Hajar NS ${ }^{1}$, Lee $\mathrm{SY}^{2}$, Mohamed $\mathbf{R}^{2}$ \& Saiful-Nizam $\mathbf{T}^{1}$ \\ ${ }^{1}$ Bio Aromatic Research Centre of Excellence, Universiti Malaysia Pahang, Lebuhraya Tun Razak, 26300 Gambang, \\ Pahang, Malaysia \\ ${ }^{2}$ Forest Biotech Laboratory, Department of Forest Management, Faculty of Forestry, Universiti Putra Malaysia, 43400 \\ UPM Serdang, Selangor, Malaysia \\ *msyafik@ump.edu.my
}

Submitted August 2019; accepted January 2020

\begin{abstract}
Aquilaria hirta is one of the agarwood tree species in Malaysia that produces a unique resinous wood and essential oil used in perfumery, medicinal, cosmetic and religious ceremonies. Currently, it has been listed as vulnerable (VU) and threatenad species in the IUCN Red List. This study aims to characterise the morphology of $A$. hirta via scanning electron microscopic analysis, and to identify the volatile chemical compounds of the wood and its essential oil using gas chromatography-flame ionisation detector and gas chromatography-mass spectrometry analyses. Aquilaria hirta was identified by the presence of hirsute on the abaxial side of leaves and midrib. The field emission scanning electron microscope analysis showed plant vessel pits can be seen in the healthy wood images compared with resinous wood images due to presence of resin and microorganisms. A total of 19 compounds were identified in resinous A. hirta wood consisting of $5.97 \%$ sesquiterpenes and $20.32 \%$ oxygenated sesquiterpenes. The major compounds are kessane, $\gamma$-cadinene, $\alpha$-caryophyllene, $\beta$-caryophylene and caryophyllene oxide. There were 35 compounds found in A. hirta oil comprising $0.45 \%$ monoterpenes, $23.51 \%$ sesquiterpenes and $19.53 \%$ oxygenated sesquiterpenes. Major compounds detected were $\gamma$-cadinene, nor-ketoagarofuran, allo-aromadendrene, $\gamma$-gurjunene and $\beta$-gurjunene. This study provides a reference for the identification of $A$. hirta species based on morphology evaluation and volatile chemical compounds profile of the essential oil and wood.
\end{abstract}

Keywords: Agarwood, solid phase microextraction, sesquiterpene, sesquiterpenoid, monoterpenes

\section{INTRODUCTION}

Agarwood is a resinous wood formed in Aquilaria species trees as a result of mechanical wounding followed by fungal infection. The wood and essential oil are being used in religious ceremonies, perfumery, medicinal and cosmetic industries. Since the past several years, exploitation of agarwood trees has been increasing due to the high demand from consumers. This has resulted in depletion of the natural resource, hence raising the price of agarwood. Since 2004, Aquilaria species have been listed in Appendix II of the Convention on the International Trade in Endangered Species (CITES 2017). Aquilaria hirta is one of the five Aquilaria species that produce fragrant resin in Malaysia (Faridah-Hanum et al. 2009). Aquilaria hirta is classified as vulnerable by the International Union for Conservation of Nature (IUCN) Red List of Threatened Species (IUCN 2015). Therefore, scientific conservation effort must be conducted to characterise A. hirta tree, its essential oil, and the chip wood for creating a standard reference for this species. This plant is also considered as less explored agarwood species in Malaysia as very little reports on taxonomic and chemical profiles are available compared with A. malaccensis ( $\mathrm{Ng}$ et al. 1997).

Aquilaria hirta could be identified by the presence of hirsute on the abaxial side of leaves and midrib. Species identification solely based on leaf morphology is challenging since the impact of different environmental condition such as climate change and soil composition lead to the changing of plant morphology (Lee et al. 2011). Thus, identification of $A$. hirta structures through scanning electron microscope is necessary for characterisation of physiological structures as well as the wood tissue of resinous and healthy part of the plant. 
Agarwood and its essential oil have different quality or grades. Traditionally, physical appearances such as odour and colour have been used to grade their qualities. The method depends on human sense which is subjective, time-consuming, and has poor reproducibility and high labour expense. In Malaysia, some methods had been proposed for agarwood grading (Mazlan \& Dahlan 2010, Nor Azah et al.2013, MTIB 2014). Chemical compositions in agarwood and the oil are different among the grades. Therefore, there is a requirement for agarwood to be graded to its chemical profiles to ensure quality and originality. Gas chromatography-mass spectrometry (GC-MS) and gas chromatography-flame ionisation detector (GC-FID) are powerful methods to identify fingerprint compounds in volatile samples (Marriot et al. 2001). Some volatile marker compounds were identified using the methods for $A$. malaccensis, namely, $\alpha$-guaiene, $\beta$-agarofuran, $\alpha$-bulnesene, jinkoh-eremol, kusunol, selina-3,11-dien-9-one, oxo-agarospirol and guaiaa-1(10),11-dien-15, 2-olide (Tajuddin \& Yusoff 2010). A total of 33 sesquiterpene hydrocarbons were identified using these methods as well as advanced analysis using GC $\times$ GC/TOFMS for A. malaccensis as an effort to establish a universal standard to classify the aromatic products from Aquilaria spp. (Tajuddin et al. 2016) .

This study aims to characterise the morphology of A. hirta via scanning electron microscopic analysis, and to identify the volatile chemical compounds of the wood and its essential oil using GC-FID and GC-MS analyses.

\section{MATERIALS AND METHODS}

\section{Plant materials}

Aquilaria hirtawood and leaf samples were obtained from Rompin Forest, Pahang $\left(02^{\circ} 31.6^{\prime} \mathrm{N}\right.$, $103^{\circ} 46.8^{\prime} \mathrm{E}, 29 \mathrm{~m}$ asl). The voucher specimen was kept at the Universiti Malaysia Pahang herbarium collection (BARCE03).

\section{Sample preparation}

Both healthy and resinous woods were dried in an oven at $40{ }^{\circ} \mathrm{C}$ for 7 days. The dried wood was chopped and milled (1.0 mm powder size). Some woods and leaf samples were kept with maximum dimensions of $3 \mathrm{~cm} \times 3 \mathrm{~cm} \times 3 \mathrm{~cm}$ and $3 \mathrm{~cm} \times 3 \mathrm{~cm}$ respectively for scanning electron microscope analysis.

\section{Microscopic morphology analysis}

The microstructures for fresh leaves were observed using scanning electron microscope equipped with electron detector. High resolution images were obtained with a magnification range from 10-500×. Electron microscopy images of dried healthy and resinous woods were obtained in a field emission scanning electron microscope. High voltage power of $15 \mathrm{kV}$ and high vacuum mode were used during the analysis.

\section{Extraction of essential oil}

An amount of $20 \mathrm{~g}$ of resinous agarwood powder was immersed in $200 \mathrm{~mL}$ distilled water prior to hydrodistillation in a clevenger type apparatus for 12 hours. The oil was taken up in hexane and anhydrous sodium sulfate was added to remove water content. The solution was purged with nitrogen gas $\left(\mathrm{N}_{2}\right)$ to remove hexane, then stored at $4{ }^{\circ} \mathrm{C}$ in glass amber vials prior to $\mathrm{GC}$ analysis.

\section{Solid phase microextraction (SPME)}

Healthy and resinous agarwood powder (each $0.2 \mathrm{~g}$ ) were transferred into different $4 \mathrm{~mL}$ clear glass vial with PTFE/silicone septum. The samples were exposed to SPME fibre, which was a 50/30 $\mu \mathrm{m}$ DVB/CAR/PDMS (divinylbenzene/ carboxen/polydimethylsiloxane) at $40{ }^{\circ} \mathrm{C}$ for $30 \mathrm{~min}$ for volatile headspace adsorption. The fibre was then left for $3 \mathrm{~min}$ in the GC glass liner for thermal desorption at $240{ }^{\circ} \mathrm{C}$.

\section{Gas chromatography analyses}

Chemical profiling for wood and oil samples were conducted via GC system equipped with GC-FID and quadrupole mass spectrometer detector (GC-MS). The volatile compounds were carried by purified helium through DB-1ms capillary column $(30 \mathrm{~m}$ in length $\times 0.25 \mathrm{~mm}$ inner diameter $\times 0.25 \mu \mathrm{m}$ film thickness) at a flow rate of $1.2 \mathrm{~mL} \mathrm{~min}^{-1}$. The GC-MS system was set with ionisation energy of $70 \mathrm{eV}$. Oven programming was set from 60 to $230{ }^{\circ} \mathrm{C}(3 \mathrm{~min}$ hold) at $3{ }^{\circ} \mathrm{C} \mathrm{min}{ }^{-1}$ for wood samples with $230{ }^{\circ} \mathrm{C}$ used as inlet and detector temperatures. Oil 
sample was run with oven programming of 80 to $250{ }^{\circ} \mathrm{C}(3 \mathrm{~min}$ hold $)$ at $3{ }^{\circ} \mathrm{C} \mathrm{min}^{-1}$ and $250{ }^{\circ} \mathrm{C}$ as inlet and detector temperatures.

\section{Identification of chemical compounds}

The components were identified by comparing their retention indices and mass spectra with published data by National Institute of Standards Technology (NIST). Compounds determination for GC-MS were based on $>90 \%$ similarity index of that NIST library. Kovats retention indices were calculated using a homologous series of n-alkanes $\left(\mathrm{C}_{7}-\mathrm{C}_{20}\right)$ using equation 1 for GC-FID.

$$
I=100 \times\left[n+(n-n) \frac{\log \left(t_{r}^{\prime} \text { unkown }\right)-\log \left(t_{r}^{\prime} n\right)}{\log \left(t_{r}^{\prime} N\right)-\log \left(t_{r}^{\prime} n\right)}\right]
$$

$$
\begin{aligned}
\mathrm{I}= & \text { Kovats retention index } \\
\mathrm{n}= & \text { Number of carbon atom in smaller } \\
& \text { n-alkane } \\
\mathrm{N}= & \begin{array}{l}
\text { Number of carbon atom in larger } \\
\text { n-alkane }
\end{array} \\
\mathrm{t}_{\mathrm{r}}^{\prime}= & \begin{array}{l}
\text { Retention time of unknown chemical } \\
\text { compound }
\end{array} \\
\mathrm{t}_{\mathrm{r}}^{\prime} \mathrm{n}= & \begin{array}{l}
\text { Retention time of carbon atom in smaller } \\
\text { n-alkane }
\end{array} \\
\mathrm{t}_{\mathrm{r}}^{\prime} \mathrm{N}= & \begin{array}{l}
\text { Retention time of carbon atom in larger } \\
\text { n-alkane }
\end{array}
\end{aligned}
$$

\section{RESULTS AND DISCUSSION}

In order to identify a species in Aquilaria genus, observation must also be made on the flowers and fruits. Unfortunately, the morphological characteristics of those plant parts were not available since samples were obtained outside breeding season unknowingly. According to the Anonymous (2015), the colour of the A. hirta flower appeared to be whitish to light yellow and the floral tube is cylindrical. It has small hairs on the surface and more pointed at the base compared with other Aquilaria species. The shape of the fruit capsule is oblanceolate acute and has a cuneate base, sharp apex, as well as a hairy texture. Being a timber, Aquilaria species bear flowers and fruits when they mature at 7-9 years of age. This means the botanical identification of agarwood can take years. Therefore, morphology evaluation using scanning electron microscopic analysis of herbarium sample of the leaf can be an alternative for species identification of Aquilaria spp.

Healthy A. hirta wood has a pale beige colour while the affected wood is dark brown or black due to the increased mass and wood density from resin development as a result of the plant defense system (Tajuddin et al. 2016). Microscopic observation under light microscope revealed that phloem and parenchyma cells are important living cells for biosynthesis of agarwood in Aquilaria spp. as brownish substances were found in both structures (Mohamed et al. 2013).

Qualitative analysis of the structures of healthy and resinous part of $A$. hirta obtained using field emission scanning electron microscope displayed the presence of agarwood resin (Figure 1). The surface of infected or resinous wood showed extensive degradation (Figure 1b(i)) compared with healthy wood (Figure 1a(i)). Vessel pits (red arrow) can be seen in the healthy wood images (Fig 1a(ii-iii)) compared with resinous wood images (Fig 1b(ii-iii)) due to presence of resin and microorganisms. The penetration of microorganism into the wood matrix is the most probable cause of the observed structure in Figure 1b(i) (Gutarowska et al. 2015). Therefore, besides transporting water to adjacent tracheary elements in flowering plants, vessel pits can be used as a phylogenetic marker to identify Aquilaria spp. (Jansen et al. 2004).

Table 1 shows the chemical composition of volatile $A$. hirta wood and essential oil based on GC analysis. A total of 47 compounds were identified in the samples using GC-FID and GC-MS. A total of 19 compounds were found in the resinous part of $A$. hirta comprising $5.97 \%$ sesquiterpenes and $20.32 \%$ sesquiterpenoid. The identified sesquiterpenoid compounds were kessane, epoxybulnesene, caryophyllene oxide, 7-epi- $\gamma$-eudesmol epi- $\alpha$-cadinol, $\alpha$-bisabolol, selina-4,11-dien-14-oic acid and selina-3,11dien-14-oic acid where kessane was the highest (15.39\%). Meanwhile, healthy A. hirta wood contained $2.17 \%$ sesquiterpenes and $1.41 \%$ sesquiterpenoid and caryophyllene oxide was the main sesquiterpenoid constituent $(0.71 \%)$.

There were 35 compounds found in $A$. hirta essential oil which contained $0.45 \%$ monoterpenes, $23.51 \%$ sesquiterpenes and $19.53 \%$ sesquiterpenoid. $\delta$-Cadinene $(11.19 \%)$ produced the highest percentage area among sesquiterpene compounds for $A$. hirta oil while the highest percentage area of sesquiterpenoid compounds was nor-ketoagarofuran $(9.40 \%)$. 


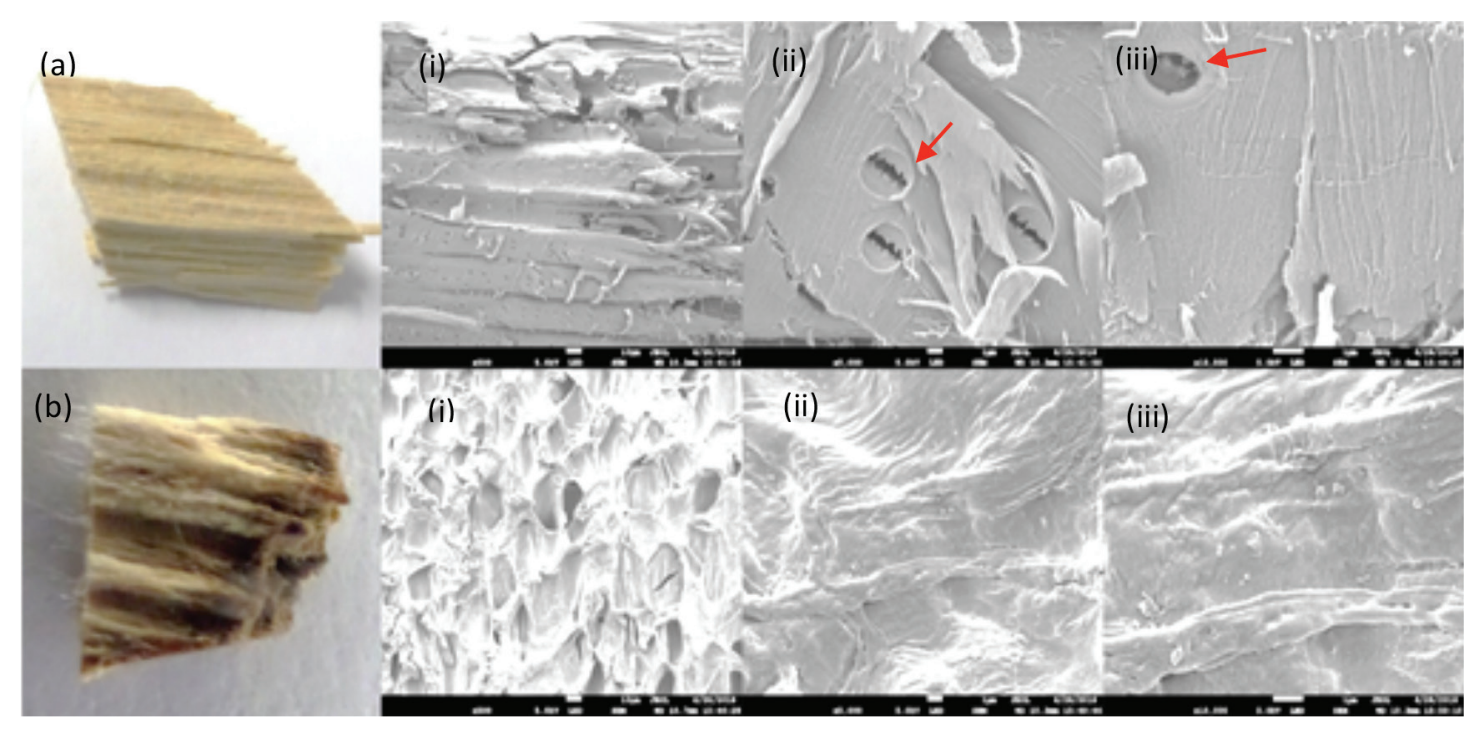

Figure 1 Transverse section and microstructure images of $A$. hirta wood: (a) pale beige healthy wood and (b) brown resinous wood and their field emission scanning electron microscope images at (i) $500 \times$, (ii) $5000 \times$ and (iii) $10000 \times$

Major volatile compounds detected in the $A$. hirta essential oil were $\gamma$-cadinene $(11.19 \%)$, norketoagarofuran $(9.40 \%)$, allo-aromadendrene $(4.34 \%), \gamma$-gurjunene $(3.42 \%)$, and $\beta$-gurjunene $(1.93 \%)$.

Identification of volatile chemical compounds is essential for grading and quality control purposes (Nor Azah et al. 2008, Pripdeevech et al. 2011, Tajuddin et al. 2013). In this study, we found that the agarwood samples were rich in terpene groups dominated by sesquiterpenoid, sesquiterpenes and monoterpenes. The quality of agarwood is increased with the increase in resin yield (Pasaribu et al. 2015). Compounds that are classified as marker compounds of agarwood essential oil include 4-phenyl-2butanone, $\alpha$-guaiene, $\beta$-agarofuran, $\alpha$-bulnesene, nor-ketoagarofuran, agarospirol, jinkoh-eremol, kusunol, dehydrojinkoh-eremol and selina3,11-dien-9-one (Ishihara et al. 1993, Tajuddin \& Yusoff 2010). Interestingly, some of the marker compounds also present in both $A$. hirta wood and oil samples as listed in the Table 1. Major compounds detected in the essential oil extracted from the in vitro shoots of $A$. hirta are tetradecanal, hexadecanoic acid, methyl linoleate, linoleic acid, isophytol and phytol acetate (Hassan et al. 2011). In this study, the existence of the marker compounds identified by the previous researchers are verified for both A. hirta wood and oil samples.
The nature of agarwood formation is sophisticated due to many factors involved causes a challenge in determination of quality. There are several aspects that may result in different chemical constituents of agarwood and their essential oils including the origin of the species, the stimulation method of agarwood resin and method of extraction of agarwood oils (Naef 2011, Hashim et al. 2014). Deep and Tajuddin (2019) proposed that agarwood oil of specific origin should be classified separately based on their chemical compositions and the grading should be based on sesquiterpenoid contents in the pure essential oil. This study provided additional database for the agarwood identity and was designed to identify chemical compounds from the best sample from the wild only. The sample was collected from only one location in Endau-Rompin Forest and was considered as wild and had the best quality which meant it did not undergo inoculation process (Mohamed \& Lee 2016). However, more sample collection will be carried out in future and statistical analysis should be included towards creating the standard reference.

\section{CONGLUSIONS}

This plant was verified as $A$. hirta based on morphology evaluation of the leaf and wood via scanning electron microscopic analysis. Major 
Table 1 Chemical composition of volatile Aquilaria hirta wood and essential oil based on gas chromatography analysis

\begin{tabular}{|c|c|c|c|c|c|c|}
\hline \multirow{2}{*}{ Chemical compound } & \multirow{2}{*}{$\begin{array}{c}\text { Molecular } \\
\text { formula }\end{array}$} & \multirow{2}{*}{ RI } & \multicolumn{3}{|c|}{ Relative peak area $(\%)$} & \multirow{2}{*}{ Identification } \\
\hline & & & HW & RW & $\mathrm{EO}$ & \\
\hline \multicolumn{7}{|l|}{ Aldehyde and ketone } \\
\hline Benzaldehyde & $\mathrm{C}_{7} \mathrm{H}_{6} \mathrm{O}$ & 939 & 0.20 & 0.85 & - & FID, MS \\
\hline 4-phenyl-2-butanone & $\mathrm{C}_{10} \mathrm{H}_{12} \mathrm{O}$ & - & - & - & 3.75 & MS \\
\hline \multicolumn{7}{|l|}{ Monoterpenoid } \\
\hline Isoeugenol & $\mathrm{C}_{10} \mathrm{H}_{12} \mathrm{O}_{2}$ & - & - & - & 0.45 & FID \\
\hline \multicolumn{7}{|l|}{ Sesquiterpene } \\
\hline$\alpha$-Copaene & $\mathrm{C}_{15} \mathrm{H}_{24}$ & 1367 & - & - & & FID \\
\hline$\alpha$-Gurjunene & $\mathrm{C}_{15} \mathrm{H}_{24}^{2+}$ & 1403 & 0.08 & 0.15 & 0.50 & FID, MS \\
\hline Isocaryophyllene & $\mathrm{C}_{15} \mathrm{H}_{24}^{24}$ & 1411 & 0.60 & - & 1.55 & FID \\
\hline$\alpha$-Longipinene & $\mathrm{C}_{15} \mathrm{H}_{24}$ & 1419 & - & - & 0.59 & FID \\
\hline$\beta$-Gurjunene & $\mathrm{C}_{15} \mathrm{H}_{24}$ & 1425 & - & - & 0.13 & FID \\
\hline$\beta$-Caryophyllene & $\mathrm{C}_{15} \mathrm{H}_{24}^{24}$ & 1433 & 0.50 & 1.05 & 1.93 & FID \\
\hline Aromadendrene & $\mathrm{C}_{15} \mathrm{H}_{24}$ & 1436 & - & - & 0.56 & FID, MS \\
\hline$\alpha$-Caryophyllene & $\mathrm{C}_{15} \mathrm{H}_{24}^{24}$ & 1445 & 0.27 & 1.38 & 1.55 & FID \\
\hline$\gamma$-Selinene & $\mathrm{C}_{15} \mathrm{H}_{24}$ & 1455 & - & - & 0.79 & FID \\
\hline Alloaromadendrene & $\mathrm{C}_{15} \mathrm{H}_{24}$ & 1460 & - & 0.36 & 4.34 & FID \\
\hline$\alpha$-Curcumene & $\mathrm{C}_{15} \mathrm{H}_{22}$ & 1467 & - & 0.51 & 0.14 & FID \\
\hline$\gamma$-Gurjunene & $\mathrm{C}_{15} \mathrm{H}_{24}^{22}$ & 1473 & 0.13 & 0.20 & 3.42 & FID, MS \\
\hline$\delta$-Guaiene & $\mathrm{C}_{15} \mathrm{H}_{24}$ & 1491 & 0.08 & - & 0.47 & FID, MS \\
\hline$\gamma$-Cadinene & $\mathrm{C}_{15} \mathrm{H}_{24}^{2+}$ & 1499 & 0.34 & 2.14 & 11.19 & FID \\
\hline$\delta$-Cadinene & $\mathrm{C}_{15} \mathrm{H}_{24}$ & 1510 & - & - & 0.61 & FID \\
\hline$\alpha$-Calacorene & $\mathrm{C}_{15} \mathrm{H}_{20}$ & 1525 & 0.17 & - & - & FID \\
\hline Dehydroaromadendrene & $\mathrm{C}_{15} \mathrm{H}_{24}^{20}$ & 1534 & - & 0.18 & 0.50 & FID \\
\hline \multicolumn{7}{|l|}{ Oxygenated sesquiterpene } \\
\hline Dihydro- $\beta$-agarofuran & $\mathrm{C}_{15} \mathrm{H}_{26} \mathrm{O}$ & 1486 & & 0.72 & & FID \\
\hline Kessane & $\mathrm{C}_{15} \mathrm{H}_{26} \mathrm{O}$ & 1516 & - & 15.39 & 1.64 & FID, MS \\
\hline Cis-nerolidol & $\mathrm{C}_{15} \mathrm{H}_{26} \mathrm{O}$ & 1553 & 0.40 & - & - & FID \\
\hline nor-ketoagarofuran & $\mathrm{C}_{14} \mathrm{H}_{22} \mathrm{O}_{2}$ & 1563 & - & - & 0.68 & FID \\
\hline Epoxybulnesene & $\mathrm{C}_{15} \mathrm{H}_{24} \mathrm{O}$ & 1578 & - & 0.62 & 9.40 & FID \\
\hline Caryophyllene oxide & $\mathrm{C}_{15} \mathrm{H}_{24} \mathrm{O}$ & 1582 & - & 0.93 & - & FID \\
\hline 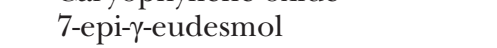 & $\mathrm{C}_{15} \mathrm{H}_{26} \mathrm{O}$ & 1598 & 0.71 & 0.41 & - & FID \\
\hline Guaiol & $\mathrm{C}_{15} \mathrm{H}_{26} \mathrm{O}$ & 1608 & 0.11 & - & - & FID \\
\hline$\gamma$-Eudesmol & $\mathrm{C}_{15} \mathrm{H}_{26} \mathrm{O}$ & 1615 & - & - & - & FID, MS \\
\hline Agarospirol & $\mathrm{C}_{15} \mathrm{H}_{26} \mathrm{O}$ & 1620 & 0.12 & - & 0.1 & FID \\
\hline$\beta$-Eudesmol & $\mathrm{C}_{15} \mathrm{H}_{26} \mathrm{O}$ & 1632 & - & 0.33 & - & FID \\
\hline epi- $\alpha$-Cadinol & $\mathrm{C}_{15} \mathrm{H}_{26} \mathrm{O}$ & 1635 & - & 0.88 & 0.14 & FID \\
\hline$\alpha$-Eudesmol & $\mathrm{C}_{15} \mathrm{H}_{26} \mathrm{O}$ & 1639 & - & - & 0.86 & FID \\
\hline Kusunol & $\mathrm{C}_{15} \mathrm{H}_{26} \mathrm{O}$ & 1656 & - & - & 0.99 & FID \\
\hline Dehydrojinkoh-eremol & $\mathrm{C}_{15} \mathrm{H}_{24} \mathrm{O}$ & 1673 & - & 0.19 & - & FID \\
\hline$\alpha$-Bisabolol & $\mathrm{C}_{15} \mathrm{H}_{26} \mathrm{O}$ & 1686 & - & 0.55 & - & FID \\
\hline Selina-3,11-dien-9-one & $\mathrm{C}_{15} \mathrm{H}_{22} \mathrm{O}$ & 1695 & 0.07 & - & 0.48 & FID \\
\hline Rotundone & $\mathrm{C}_{15} \mathrm{H}_{22} \mathrm{O}$ & 1700 & - & - & 0.74 & FID \\
\hline Selina-3,11-dien-9-ol & $\mathrm{C}_{15} \mathrm{H}_{24} \mathrm{O}$ & 1715 & - & - & 0.58 & FID \\
\hline Selina-4,11-dien-14-oic acid & $\mathrm{C}_{15} \mathrm{H}_{22} \mathrm{O}_{2}$ & 1725 & - & 0.30 & 1.57 & FID \\
\hline Selina-3,11-dien-9-al & $\mathrm{C}_{15} \mathrm{H}_{22} \mathrm{O}$ & 1734 & - & - & 0.86 & FID \\
\hline Selina-4,11-dien-14-al & $\mathrm{C}_{15} \mathrm{H}_{22} \mathrm{O}$ & 1765 & - & - & 0.40 & FID \\
\hline Guaia-1 (10),11-dien-15-oic acid & $\mathrm{C}_{15} \mathrm{H}_{22} \mathrm{O}_{2}$ & 1812 & - & - & 0.46 & FID \\
\hline Karanone & $\mathrm{C}_{15} \mathrm{H}_{20} \mathrm{O}$ & 1821 & - & - & 0.28 & FID \\
\hline Oxo-agarospirol & $\mathrm{C}_{15} \mathrm{H}_{24} \mathrm{O}_{2}$ & 1836 & - & - & 0.35 & FID \\
\hline \multicolumn{7}{|l|}{ Carboxylic acid } \\
\hline$n$-Hexadecanoic acid & $\mathrm{C}_{16} \mathrm{H}_{32} \mathrm{O}_{2}$ & - & - & - & 13.04 & MS \\
\hline trans-9-Octadecenoic acid & $\mathrm{C}_{18} \mathrm{H}_{34} \mathrm{O}_{2}^{2}$ & - & - & - & 11.20 & MS \\
\hline Total aldehyde and ketone & & & 0.20 & 0.85 & 3.75 & \\
\hline Total monoterpenoid & & & - & - & 0.45 & \\
\hline Total sesquiterpene & & & 2.17 & 5.97 & 28.27 & \\
\hline Total sesquiterpenoid & & & 1.41 & 20.32 & 19.84 & \\
\hline Total carboxylic acid & & & - & - & 24.24 & \\
\hline
\end{tabular}

$\mathrm{RI}=$ retention indices based on DB-1 ms capillary column, $\mathrm{HW}$ =healthy wood, $\mathrm{RW}=$ resinous wood, $\mathrm{EO}=$ essential oil, FID = detection via GC-FID, MS = identification via GC-MS 
volatile chemical compounds were successfully identified in both healthy and resinous wood as well as the essential oil by using GC-MS and GC-FID. Since $A$. hirta is classified as vulnerable and is the least explored Malaysia agarwood species, this study will provide a reference database for A. hirta species verification and quality analysis of the agarwood as well as the essential oil based on the volatile chemical compounds. In future, sustainable agarwood supply in the global market can be established by proper identification and quality control analysis to address the problem of fraud in the agarwood industry.

\section{ACKNOWLEDGEMENTS}

We acknowledge the financial support awarded by the Ministry of Higher Education Malaysia (Fundamental Research Grant Scheme no. FRGS/1/2016/STG01/UMP/02/1) to Universiti Malaysia Pahang.

\section{REFERENCES}

Anonymous. 2015. Manual to identification Aquilaria species in Peninsular Malaysia. Forestry Department Peninsular Malaysia, Kuala Lumpur.

CITES. 2017. Convention on international trade in endangered species of wild fauna and flora. Retrieved from www.cites.org.

Deep K \& Tajuddin SN. 2019. King of scents: agarwood. Fragrance 44: 42-56.

Faridah-Hanum I, Mustapa MZ, Lepun P, Tuan Marina TI, Nazre M, Alan R \& Mohamed R. 2009. Notes on the distribution and ecology of Aquilaria Lam. (Thymelaeaceae) in Malaysia. The Malaysian Forester 72: 247-259.

Gutarowska B, Celikkol-Aydi S, Bonifay B et al. 2015. Metabolomic and high-throughput sequencing analysis-modern approach for the assessment of biodeterioration of materials from historic buildings. Frontiers in Microbiology 6: 979. https:// doi.org/10.3389/fmicb.2015.00979.

Hassan NH, Ali NAM, Zainudin F \& Ismail H. 2011. Effect of 6-benzylaminopurine (BAP) in different basal media on shoot multiplication of Aquilaria hirta and detection of essential oils in the in vitro shoots. African Journal of Biotechnology 10: 10500-10503. https://doi. org /10.5897/AJB11.121.

Hashim Y, Yumi ZH, Ismail N I \& Abbas P. 2014. Analysis of chemical compounds of agarwood oil from different species by gas chromatography mass spectrometry (GCMS). IIUM Engineering Journal 15: 55. https:// doi.org/10.31436/iiumej.v15i1.469.

Ishihara M, Tsuneya T, Shiga M \& Uneyama K. 1993. Components of the volatile concentrate of agarwood. Journal of Essential Oil Research 5: 283-289. https:/ / doi.org/10.1080/10412905.1993.9698221.
IUCN. 2015. The IUCN Red List of Threatened Species. Retrieved from www.iucnredlist.org.

Jansen S, BaAs P, Gasson P, Lens F \& SMets E. 2004. Variation in xylem structure from tropics to tundra: evidence from vestured pits. Proceedings of the National Academy of Sciences of the United States of America 101: 88338837. https://doi.org/10.1073/pnas.0402621101.

Lee SY, Weber J \&, Mohamad R. 2011. Genetic variation and molecular authentication of selected Aquilaria species from natural populations in Malaysia using RAPD and SCAR markers. Asian Journal of Plant Sciences 10: 202-211. https://doi.org/10.3923/ ajps.2011.202.211

MTIB (Malaysian Timber Industry Board). 2014. Panduan pengelasan produk gaharu Malaysia. Lembaga Perindustrian Kayu Malaysia, Kuala Lumpur.

Marriot PJ, Shellie R \& Cornwell C. 2001. Gas chromatographic technologies for the analysis of essential oils. Journal of Chromatography 936: 1-22. https://doi.org/10.1016/S0021-9673(01)01314-0.

MaZlan M \& Dahlan T. 2010. Penggredan dan pemprosesan gaharu. Prosiding Seminar Kebangsaan dan Pameran Gaharu. 22-23 March 2010, Serdang.

Mohamed R \& Lee SY. 2016. Keeping up appearances: agarwood grades and quality. PP 149-167 in Mohamed R (ed) Agarwood Science Behind The Fragrance. Springer Science, Singapore. https:/ / doi. org/10.1007/978-981-10-0833-7_1.

Mohamed R, Wong M, Halis R. 2013. Microscopic observation of 'gaharu' wood from Aquilaria malaccensis. Pertanika Journal of Tropical Agricultural Science 36: 43-50.

NAEF R. 2011. The volatile and semi-volatile constituents of agarwood, the infected heartwood of Aquilaria species: a review. Flavour and Fragrance Journal 26: 73-89. https://doi.org/10.1002/ffj.2034.

Ng LT, Chang YS \& Abdul Kadir A. 1997. A review on agar (gaharu) producing Aquilaria species. Journal of Tropical Forest Products 2: 272-285.

Nor Azah M, Chang YS, Mailina J Et al. 2008. Comparison of chemical profile of selected gaharu oils from Peninsular Malaysia. The Malaysia Journal of Analytical Sciences 12: 338-340.

Nor Azah MA, Saidatul Husni S, Mailina J, Sahrim L, Abdul Majid J, Mohd Faridz Z. 2013. Classification of agarwood (gaharu) by resin content. Journal Tropical Forest Sciences 25: 213-219.

Pasaribu G, Waluyo TK \& Pari G. 2015. Analysis of chemical compounds distinguisher for agarwood qualities. Indonesian Journal of Forestry Research 2: 1-7. https:/ / doi.org/10.20886/ijfr.2015.2.1.1-7.

Pripdeevech P, Khummueng W \& Park SK. 2011. Identification of odor-active components of agarwood essential oils from Thailand by solid phase microextractionGC/MS and GC-O. Journal of Essential Oil Research 23: 46-53. https://doi.org/10.1080/10412905.20 11.9700468 .

Tajuddin SN, Muhamad NS,Yarmo MA \& Yusoff MM. 2013. Characterization of the chemical constituents of agarwood oils from Malaysia by comprehensive twodimensional gas chromatography-time-of-flight mass spectrometry. Mandeleev Communications 23: 51-52. https://doi.org/10.1016/j.mencom.2013.01.019. 
Tajuddin SN \& Yusoff MM. 2010. Chemical composition of volatile oils of Aquilaria malaccensis Benth. (Thymelaeaceae) from Malaysia. Natural Product Communications 5: 1965-1968. https://doi. org/10.1177/1934578X1000501229.
Tajuddin SN, Yusoff MM \& Aizal CM. 2016. Resolution of complex sesquiterpene hydrocarbons in Aquilaria malaccensis volatile oils using gas chromatography technique. Pp 103-124 in Mohamed R (ed) Agarwood Science Behind The Fragrance. Springer Science, Singapore. https://doi.org/10.1007/978-981-100833-7_1. 